\section{PP-053当科における局所進行性前立腺癌に対す る治療成績の検討}

\section{富山大学大学院医学薬学研究部腎泌尿器科学講座 \\ 保田賢司, 旦尾嘉宏, 飯田 裕朗, 一松 啓介, 今村 朋理, 伊藤 崇敏, 森井 章裕, 渡部 明彦, 野崎 哲夫, 藤内 靖喜, 小宮 顕, 布施 秀樹}

【目的】局所進行性前立腺癌の治療成績について内分泌療 法と手術療法でレトロスペクティブに比較検討した。【対 象と方法】1981 年 3 月から 2007 年 10 月に局所進行性前 立腺癌と診断され内分泌療法を施行した 75 例（中央值； 78 歳）と手術療法を施行した 57 例（中央值；68歳）を 刘象とした（観察期間は内分泌療法が 9-259 ケ月；中央值 41 ケ月、手術療法が 14-220 ケ月; 中央值 58 ケ月であった)。 手術療法群のうち 52 例に術前補助療法を施行した。また 術後補助療法を施行した症例は 41 例であった（ホルモン 療法；36 例、放射線照射；18 例、化学療法； 5 例)。臨床 的病期診断は、直腸診、経直腸超音波、MRI、CT、骨シ ンチにて行った。PSA 再燃日および再発日は 3 回連続上 昇した最初の上昇ポイント時とした。PSA 再発 (再然) 率、 癌特異的生存率、全生存率揖よび PSA 再発の予測因子に ついて検討した。【結果】内分泌療法群の 5 年 PSA 非再発 率は、54.5\%であり手術療法群は、79.6\%であった。5 年癌 特異的生存率は、それぞれ $90.7 \%$ と $95.0 \%$ 、5 年全生存率は、 それぞれ 76.1\%、93.0\%であった。手術療法群でPSA 再発 の予測因子の検討を行ったところ術後補助療法の有無と病 理組織学的なリンパ節転移の有無が多変量解析で有意差を 認めた。

\section{PP-054尿路上皮癌細胞を対象とした Heme oxygenase-1 阻害剂による Gemcitabine 治療効果增強作用の検討}

\section{奈良県立医科大学泌尿器科学}

三宅 牧人, 藤本 清秀, 大西 小百合, 井上 剛志, 穴井智, 富岡 厚志, 池田 朋博, 田中 宣道, 平尾 佳彦

【目的】Heme oxygenase-1 (HO-1) は酸化ストレスなど 種々の刺激により発現が誘導され，細胞防御因子として機 能することが知られている。近年, 膵臓癌や大腸癌におい て, HO-1 が抗アポトーシス機構を介して抗癌剤および放 射線治療抵抗性と関連していることが報告されている。本 研究では, Gemcitabine (GEM) 療法におけるHO-1 阻害 剤の治療効果増強作用について検討した。【方法】膀胱癌 細胞株を対象に，各種抗癌化学剂および放射線治療におい て HO-1 阻害剂である 亜鉛プロトポルフィリン IX ( $\mathrm{ZnPP})$ を併用し，その増殖抑制効果を評価した。細胞内ヒストン /DNA 断片化複合体をELISA 法で測定し，アポトーシス を検出した。ヌードマウスを用いて膀胱癌皮下腫瘍モデル を作成し, In vivoに扔ける GEM と ZnPP 併用效果を検 討した。【結果】ZnPP を併用することで，GEMを含む各 種抗癌化学剂および放射線治療に対する感受性の充進が確 認された。特にGEM との併用では，GEM 単剂群， ZnPP 単剤群と比較して有意にアポトーシスが誘導されていた $(P<0.001)$ 。同様に, 膀胱癌皮下腫瘍モデルにおいては, GEM 単剂群, $\mathrm{ZnPP}$ 単剂群と比較して併用群では有意な腫 瘍増殖抑制効果が認められた $(P<0.01) 【$ 結論】HO-1 は 尿路上皮癌細胞において GEM 抵抗性因子として機能して おり，HO-1 阻害剂の臨床応用の可能性が示唆された。

\section{PP-055 膀胱腫瘍に対する S-1・CPT-11 併用に よる殺細胞効果の検討}

\section{慶應大学医学部泌尿器科学1), さいたま市立病院 ${ }^{2)}$}

井手 広樹1.22, 菊地 栄次 ${ }^{1}$, 服部 盛也立, 安水 洋太 ${ }^{11}$, 長谷川 政徳 ${ }^{11}$, 宮嶋 哲1), 大家 基戙1)

【目的】5-FU 系経口抗癌剤である S-1 と CPT-11を併用 し、䏽胱癌細胞に対する殺細胞効果の検討を行った。【方 法】膀胱癌細胞株 KU-19-19 を用い、5-FU の標的酵素であ る TSを real time PCR、殺細胞効果をWST assay にて 測定した。更に皮下腫瘍モデルを作成し、抗腫瘍効果を測 定した。【成績】In vitroにて殺細胞効果は 5-FU $(1.5 \mu \mathrm{g} /$ $\mathrm{ml})$ 投与群 $32.4 \pm 0.8 \% 、 \mathrm{SN} 38(0.6 \mathrm{ng} / \mathrm{ml})$ 投与群 $28.9 \pm$ $0.7 \%$ 、併用群で $74.6 \pm 0.4 \%$ 、併用群に有意な殺細胞効 果の增強を認め、in vivo にて腫瘍体積は S-1 投与群で 732 $\pm 128 \mathrm{~mm}^{3} 、 \mathrm{CPT}-11$ 投与群 $681 \pm 240 \mathrm{~mm}^{3}$ 、併用群で 404 $\pm 93 \mathrm{~mm}^{3}$ で併用群に有意な抗腫犜効果の増強を認めた。 また、 real time PCRにて 5-FU $(1.5 \mu \mathrm{g} / \mathrm{ml})$ 単独群と比 較し、5-FU,SN38 (0.6ng/ml) 併用群では TS の低下を認め、 siRNA にて KU-19-19 の TS は有意に低下し、5-FU の感受 性が増強された。結論】膀胱癌細胞において S-1,CPT-11 併用療法は単独群と比較し、有意な抗腫瘍効果の增強が 認められ、そのメカニズムとしてCPT-11によるTSの down regulationの関与が示唆された。

\section{PP-056＼cjkstart膀胱癌細胞株に対するバフィロマイシン による抗腫瘍勃果の検討}

\section{慶應義塾大学医学部泌尿器科学 \\ 吉峰 倰輔, 菊地 栄次, 長谷川 政德, 小坂 威雄, \\ 宮嶋 哲, 中川 健, 大家 基嗣}

【目的】バフィロマイシン (BMA) は滤胞型 ATPase （V-ATPase）阻害剤であり、胃癌・肺癌の細胞株でアポトー シスを誘導することが報告されている。今回われわれは膀 胱癌細胞株に対する BMAの抗腫瘍効果、アポトーシス誘 導のメカニズムにつき検討した。【方法】膀胱癌細胞株は UMUC-3、RT4 を用いた。細胞増殖抑制効果はWST-1 を 用い判定した。アポトーシスの判定、細胞周期の検討には フローサイトメターを用い、それぞれ TUNEL 法、BrdU 法にて行った。アポトーシス関連蛋白の検出はウエス夕 ンブロットにて検討した。【結果】WST-1 assay の結果、 BMA 投与群では UMUC-3にお゙て 72 時間後の細胞生存 率は5nM、10nM、20nM ではそれぞれ24\%、18\%、13\%であっ

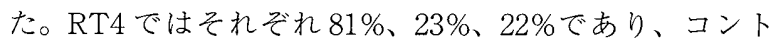
ロール群と比較し、いづれも濃度・時間依存性に抗腫瘍效 果を認めた。TUNEL では 5nM の BMA 投与後 24 時間で UMUC-3、RT4 でそれぞれ 53\%、36\%のアポトーシス細胞 を認めた。また、BrdUでは BMA 投与群でコントロール 群と比較し sub G1 細胞の増加を認めた。ウエスタンブロッ トの結果、BMA 投与群で caspase-3 の活性化を BMAの 濃度依存性に認め、膀胱癌細胞株でも caspase の活性化を 引き起こし、アポトーシスを誘導することを認めた。結論】 BMA は膀胱癌細胞に対する新たな抗腫瘍薬になる可能性 が示唆された。 